\title{
Building Facilities Management Using the Condition Prediction Process: A Case Study of Fiberglass Doors
}

\author{
Nima Amani
}

\begin{abstract}
In the last decades, Facility Management (FM) has established itself as a key building service factor.FM includes supporting services and organizing functions essential for maintaining, operating and managing physical component and material. The purpose of the paper is to develop an economical analysis for building facilities management during its service life based on limited cost. This method helps to facilities managers and engineers to make better decisions for reducing of facilities assessment costs and increasing the facilities' service life. This paper presents the preliminary development of a model involves three stages process namely data collection, economic computation and economic process optimization. This process was tested for fiberglass doors example in a building interior and exterior system. If executives can manage essential points effectively and make decisions according to a key performance index, cost can be optimized and safety can be enhanced for installation building.
\end{abstract}

Keywords: Building Management, Facilities, Process Model, Case study

\section{INTRODUCTION}

Due to the limited budget in building facilities management in developing countries, hence early replacement is uneconomical for components and facilities in a building [1]. This issue is very important on how to spend the limited financial allocation available for facilities and components management to achieve the best return for their spending. There is a lack of integration between components management time and cost decision making process in a building. Systematic prediction by condition assessment method offers help to researchers in understanding the cost decision making in the best time for building facilities management. Condition index (CI) presents the ability to form a basis for measuring rates of deterioration and prediction of condition for each component or facility [2]. The objective of this paper is to present a process to optimize the maintenance time and cost of fiberglass doors component in interior and exterior system of buildings using the condition index (CI) system. The paper presents a financial analysis using the data collected through financial and technical information. This process by using the financial analysis assists in controlling the existing investment in facilities maintenance increasing components service life and, subsequently, preventing early deterioration and components replacement in a public buildings.

\section{THE PROBLEM STATEMENT}

Most important issue to successful facilities management activities is a suitable cost allocated for a project. One of the reasons for change in facilities assessment and planning is due to limited allocation of costs [3]. Furthermore, lack of suitable costs allocation in a component assessment work could affect the facilities management implementation [4]. Therefore, building managers or owners are responsible for management and allocation of assessment costs for good management outcome [5]. Many components and facilities investment strategies lack of enough cost for components managers during its service life [6]. Hence, estimations and computations for assessment costs planning and allocation is difficult and complex [7]. Any decision making is based on existing costs and resources allocation of the buildings in facilities management activities [8]. Decision making for facilities management cost is a necessary process in management of building components and facilities [9].

\section{FACILITIES CONDITION INDEX}

Condition category guideline (CCG) [10], [11], [12], [13] has been developed by the U.S. Army corps engineers at the Engineering Research and Development Centre. This method supports engineers, assessors, and component managers with a toll that provides decisions regarding when, and where is the best to maintain and repair buildings and their key components. Condition index method is condition-based with functions which comprise an asset of major building components; condition indices; condition prediction skill; and comprehensive condition description for each CI value [14]. The condition indices were designed to support a purpose and quantitative means for component condition assessment while supporting a common language and explanation among estimators and assessors. The scale used in all of the USACERL indices ranges from 0 to 100 and is divided into seven condition categories. This method is used for every component in a building system or non-building system. This method has a comprehensive condition description for assessing component condition;

Department of Civil Engineering, Chaloos Branch, Islamic Azad University, Chaloos, Iran, nimaamani@iauc.ac.ir. (*Corresponding Author) 
predicting the future component condition; and predicting the suitable time for repair and maintenance. This model is extendable, as it has amplitude 0 to 100 . Namely, each range has a domain. For example, (100-85), (85-70), ..., and (10-0). In fact, it can have one hundred properties for assessment of component [15].

The condition category guideline (CCG) developed several condition indices for different types of component in the past years. These assessments include the pavement condition index (PCI), for road and street pavements [16], [17] the roof condition index (RCI) for built-up roofs [18], corrosion status index (CSI) of piping system [19].This method too has developed various types of civil works structures [20].

The USACERL condition indices were designed to support a purpose and quantitative means for component condition assessment while supplying a common language and explanation among users (assessor, engineer, and inspector). The scale that is used in all of the USACERL indices ranges from 0 to 100 and is divided into seven condition categories [11], [13], [15].

Overtime, condition index (CI) moves from 100 to 0 . When engineers install a component or material in a building, the condition index is 100 (excellent). Overtime, condition index for that component will reach below value 10. Basing on the definition of the CI scale, useful component failure happens when the CI falls around 10, which founds a functioning threshold limit for the model. For the unrepaired component lifecycle model, CI=10 when the time in service equals the expected service life. Hence, the profit of repair permits the deference of found rehabilitation required from component failure [21].

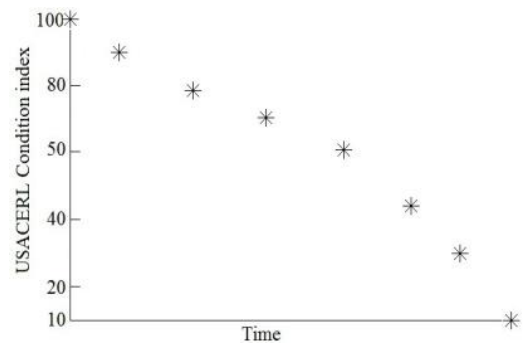

FIGURE I

CONDITION INDEX OvER TIME

The seven condition categories that set the arrangement the index scale also needs a guideline with the aim to set the computed repair time for a component concerning the each index definition (condition description for each CI value) given above. Table 1 presents these guidelines [13], [15], [21]. It is very important that the guideline (condition description) displays the categories. This is because the use of definitions would influence integrated constraints on the formulation and the indices for predicting repair time of component condition over time.
TABLE I.

CONDITION INDEX GUIDELINE

\begin{tabular}{|c|c|c|}
\hline Index & Category & Condition Description \\
\hline $\begin{array}{c}86- \\
100\end{array}$ & Excellent & $\begin{array}{l}\text { Very few defects. Component function } \\
\text { is not impaired. No immediate work } \\
\text { action is required, but routine or } \\
\text { preventive maintenance could be } \\
\text { scheduled for accomplishment. }\end{array}$ \\
\hline $71-85$ & $\begin{array}{l}\text { Very } \\
\text { Good }\end{array}$ & $\begin{array}{l}\text { Minor deterioration. Component } \\
\text { function is not impaired. No immediate } \\
\text { work action is required, but routine or } \\
\text { preventive maintenance could be } \\
\text { scheduled for accomplishment. }\end{array}$ \\
\hline $56-70$ & Good & $\begin{array}{l}\text { Moderate deterioration. Component } \\
\text { function may be somewhat impaired. } \\
\text { Routine maintenance or minor repair } \\
\text { may be required. }\end{array}$ \\
\hline $41-55$ & Fair & $\begin{array}{l}\text { Significant deterioration. Component } \\
\text { function is impaired, but not seriously. } \\
\text { Routine maintenance or minor repair is } \\
\text { required. }\end{array}$ \\
\hline $26-40$ & Poor & $\begin{array}{l}\text { Severe deterioration over a small } \\
\text { percentage of the component. Less } \\
\text { severe deterioration may be present in } \\
\text { other portions of the component. } \\
\text { Component function is seriously } \\
\text { impaired. Major repair is required. }\end{array}$ \\
\hline $11-25$ & $\begin{array}{l}\text { Very } \\
\text { Poor }\end{array}$ & $\begin{array}{l}\text { Critical deterioration has occurred over } \\
\text { a large percentage or portion of the } \\
\text { component. Less severe deterioration } \\
\text { may be present in other portions of the } \\
\text { component. Component is barely } \\
\text { functional. Major repair or less than } \\
\text { total reconstruction is required. }\end{array}$ \\
\hline $0-10$ & Failed & $\begin{array}{l}\text { Extreme deterioration has occurred } \\
\text { throughout nearly all or the entire } \\
\text { component. Component is no longer } \\
\text { functional. Major repair, complete } \\
\text { restoration, or total reconstruction is } \\
\text { required. }\end{array}$ \\
\hline
\end{tabular}

\section{THE RESEARCH GAP}

In reviewing the available literature on the maintenance management of building components, there is a dire need for specific tools to control the obvious challenges that exist in the economical system of building component maintenance management. The current gap within building component maintenance management are a consistent component assessment strategy with respect to the limited maintenance cost and a decision support analysis that can use the collected data to assist the building manager and owner to make meaningful maintenance management decisions regarding the continued usage of the components and materials.

\section{THE CASE STUDY}

Fiberglass doors are, essentially, the perfect solution to combat the effects of the highly humid conditions of Malaysia. A fiberglass door is entirely impervious to rot and rust and this tends to make it the ideal replacement door in Malaysia. Fiberglass doors also have the potential to look very aesthetically pleasing. They are available in smooth, paintable finishes as well as imitation stained wood finishes. Most fiberglass doors have the option to come prefinished from the factory with a high quality, durable finish that will often last the life of the door. 
Fiberglass doors are more expensive than steel doors [22]. These are the reasons for selection of fiberglass doors as a case study.

\section{RESEARCH, COMPUTATION AND RESUlTS}

This section describes the research methodology adapted in the study. It explains all methods requested to achieve the objectives. To achieve the objectives of the research, the methodology is divided into three stages:

- Stage I - gathering the information,

- $\quad$ Stage II - computation,

- $\quad$ Stage III - optimization.

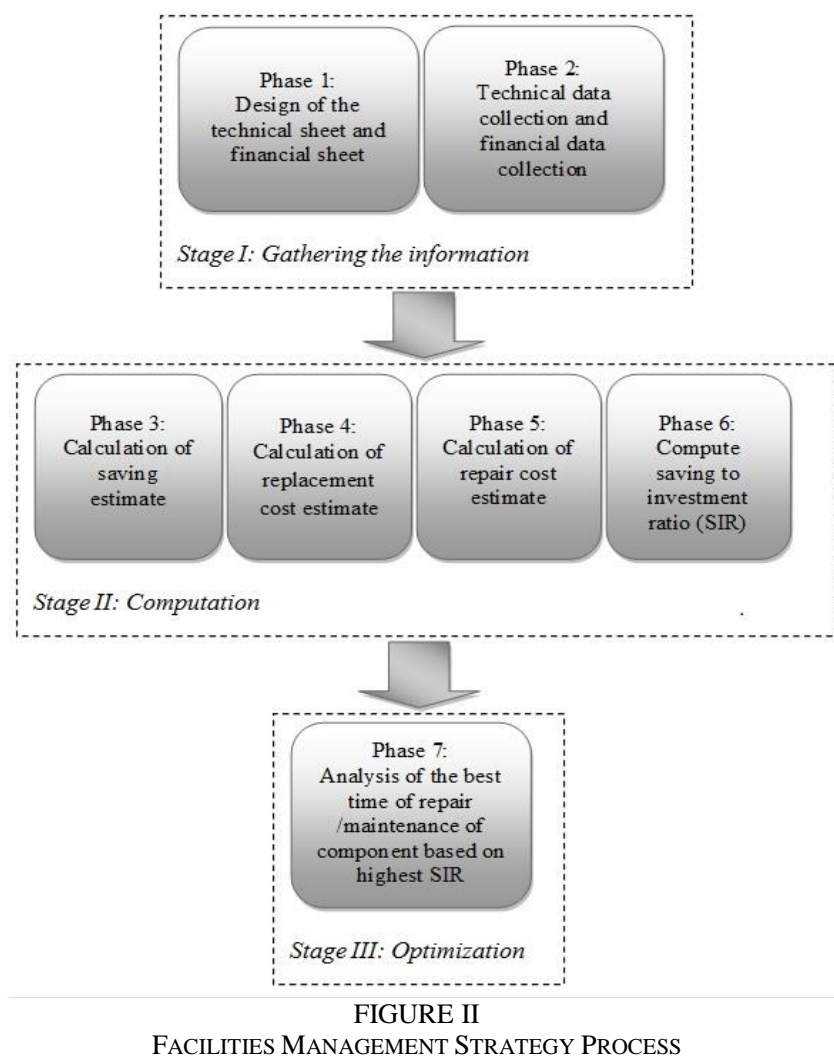

These three parts are then represented by a generic model proposed for optimum maintenance process of building component during its service life which consists of seven sequential phases of component maintenance management in a building, as shown in Fig. 2. The first two phases (Phase 1 and Phase 2) collect data required, phases three, four, five and six are developed to computation and analysis of saving estimate, component replacement cost, repair cost, and financial estimation, finally phase number seven ensures component maintenance management optimization.

The first step is gathering sufficient information on technical data related to the maintenance time of fiberglass doors from engineers' and inspectors' experiences over the past years with respect to moving the index from 100 to 10 during service life of the component. The rating sessions were carried out in small groups and at the normal work locations of the raters. The raters were first given general instructions by the researcher. This instruction is about the method of rating and determination of maintenance time for fiberglass door during its service life. Each rater is then given a copy of the rating guidelines to use as rating cues (condition description), and a set of component rating sheets, given one at a time. As each rater completed a given sheet, it was collected by the researcher. After a given set of sheets was completed, the researcher reviewed the data during the session. Any rating and assessment of maintenance time that is different more than required standard deviations from the mean were flagged for a re-rate. This was done to allow raters the opportunity to correct certain ratings that may had been marked by mistake because of misunderstanding, distraction, misinterpretation or some other reason. The individual panel members ratings were averaged to obtain mean maintenance time for fiberglass doors. As depicted in Table 2, this predictive data is to achieve the information related to the maintenance time of fiberglass doors from stand point of engineers and inspectors' experiences in past years with respect to the moving the index from 100 to 0 during component's service life. The panel's opinion, indeed, represents a broad variety of experiences from commercial piping companies, installations firms and consulting firms. As a group, the panel has experience regarding hot, cold, temperature, wet, and weather condition of related regions.

TABLE II

TECHNICAL DATA PROCESS

\begin{tabular}{|c|c|c|c|}
\hline Index & Category & $\begin{array}{c}\text { Repair } \\
\text { year }\end{array}$ & Condition Description \\
\hline 85 & $\begin{array}{l}\text { Very } \\
\text { Good }\end{array}$ & 7 & $\begin{array}{l}\text { Minor deterioration. Component } \\
\text { function is not impaired. No } \\
\text { immediate work action is required, } \\
\text { but routine or preventive maintenance } \\
\text { could be scheduled for } \\
\text { accomplishment. }\end{array}$ \\
\hline 70 & Good & 9.5 & $\begin{array}{l}\text { Moderate deterioration. Component } \\
\text { function may be somewhat impaired. } \\
\text { Routine maintenance or minor repair } \\
\text { may be required. }\end{array}$ \\
\hline 55 & Fair & 12 & $\begin{array}{l}\text { Significant deterioration. Component } \\
\text { function is impaired, but not seriously. } \\
\text { Routine maintenance or minor repair } \\
\text { is required. }\end{array}$ \\
\hline 40 & Poor & 14.5 & $\begin{array}{l}\text { Severe deterioration over a small } \\
\text { percentage of the component. Less } \\
\text { severe deterioration may be present in } \\
\text { other portions of the component. } \\
\text { Component function is seriously } \\
\text { impaired. Major repair is required. }\end{array}$ \\
\hline 25 & $\begin{array}{l}\text { Very } \\
\text { Poor }\end{array}$ & 17 & $\begin{array}{l}\text { Critical deterioration has occurred } \\
\text { over a large percentage or portion of } \\
\text { the component. Less severe } \\
\text { deterioration may be present in other } \\
\text { portions of the component. } \\
\text { Component is barely functional. } \\
\text { Major repair or less than total } \\
\text { reconstruction is required. }\end{array}$ \\
\hline 10 & Failed & 20 & $\begin{array}{l}\text { Extreme deterioration has occurred } \\
\text { throughout nearly all or the entire } \\
\text { component. Component is no longer } \\
\text { functional. Major repair, complete } \\
\text { restoration, or total reconstruction is } \\
\text { required. }\end{array}$ \\
\hline
\end{tabular}


The financial information is related to the annual maint enance cost allocated for fiberglass doors in a building that is analyzed through gathering data by financial manag ers. The financial sheet was designed basing on the data $\mathrm{c}$ ollection method covering annual cost information for mai ntenance of fiberglass doors in a building. In this study, fi nancialmanagers fill financial information from 2010 to 2 029 for predictive data (existing financial documents). Th e predictive data is selected basing on period of 20 years $t$ hat corresponds to the useful lifespan of fiberglass door $\mathrm{w}$ hich is approximately 20 years [23]. The information colle cted is stored in the saving sector for calculating the savin $\mathrm{g}$ and investment ratio (SIR) for the condition index (from 100 to 10 ) (Table 3 ). Table 3 shows the financial predicti ve information for fiberglass doors in a building. The pred ictive data is selected basing on period of 20 years that cor responds to the useful lifespan of fiberglass doors which $\mathrm{i}$ s approximately 20 years using the prediction process and the average salaries of labors and engineers from 1990 to 2009 (historical data). In this table, annual maintenance co sts are approximately 0 for first three years of operation in fiberglass doors of building systems from 2010 to 2012. This information is based on existing historical documents in building industry.

TABLE III

FINANCIAL INFORMATION

\begin{tabular}{c|c|c|c}
\hline Year & Budgeting $(\$)$ & Year & $\begin{array}{c}\text { Budgeting } \\
(\$)\end{array}$ \\
\hline 2010 & ----- & 2020 & 400 \\
\hline 2011 & ----- & 2021 & 400 \\
\hline 2012 & ----- & 2022 & 100 \\
\hline 2013 & 50 & 2023 & 100 \\
\hline 2014 & 100 & 2024 & 50 \\
\hline 2015 & 100 & 2025 & 50 \\
\hline 2016 & 150 & 2026 & 50 \\
\hline 2017 & 200 & 2027 & 50 \\
\hline 2018 & 200 & 2028 & 50 \\
\hline 2019 & 400 & 2029 & 50 \\
\hline
\end{tabular}

Table 4 illustrates the calculation of financial predictive data to achieve the saving estimate. The saving is total annual maintenance budget until maintenance time. The saving is calculated basing on the maintenance costs allocated for repair, service, inspection and clean annually in part of component maintenance until year i. The saving is estimated basing on condition index, maintenance year (technical information) and financial information for fiberglass doors in a building through the following formulas for predictive data:

$$
\left[\sum_{i=2010}^{n} \mathrm{FI}_{i}\right]
$$

Here, FI presents financial information of predictive dat $\mathrm{a}$, and $\mathrm{n}$ is Year-end of annual maintenance cost in desired index (index 85 to index 10). In this study the predictive data is important for implementation of maintenance predi ction process. The computation of saving estimate is done basing on the maintenance year in each condition index. $\mathrm{F}$ or example in Table 4, in the second row of predictive dat a (index 70), the saving is equal to sum of the financial inf ormation (Table 3) from 2010 to 2018 (9 years) plus $1 / 2$ o f 2019 (6 from 12 months).

TABLE IV

CAlCulation of SAVING ESTIMATE FOR FIBERGLASS Doors

Predictive Data

\begin{tabular}{l|c|l|c}
\hline \multicolumn{1}{c}{$\begin{array}{c}\text { Saving } \\
\text { Condition } \\
\text { Index }\end{array}$} & $\begin{array}{c}\text { Mainten } \\
\text { ance } \\
\text { Year }\end{array}$ & $\begin{array}{c}\text { Computation basing on the } \\
\text { Maintenance Year }\end{array}$ & $\begin{array}{c}\text { Result } \\
(\$)\end{array}$ \\
\hline $\begin{array}{l}\text { Saving in } \\
\text { Index 85 }\end{array}$ & 7 & $\begin{array}{l}2016 \\
\mathrm{FF}_{i} \\
\mathrm{i}=2010\end{array}$ & 400 \\
\hline $\begin{array}{l}\text { Saving in } \\
\text { Index 70 }\end{array}$ & 9.5 & $\begin{array}{l}2018 \\
\left(\sum \mathrm{FI}_{i}\right)+\left(\mathrm{FI}_{2019} / 2\right) \\
\mathrm{i}=2010\end{array}$ & 900 \\
\hline $\begin{array}{l}\text { Saving in } \\
\text { Index 55 }\end{array}$ & 12 & $\begin{array}{l}2021 \\
\sum \mathrm{FI}_{i} \\
\mathrm{i}=2010\end{array}$ & 2000 \\
\hline $\begin{array}{l}\text { Saving in } \\
\text { Index 40 }\end{array}$ & 14.5 & $\begin{array}{l}2023 \\
\left(\sum \mathrm{FI}_{i}\right)+\left(\mathrm{FI}_{2024} / 2\right) \\
\mathrm{i}=2010\end{array}$ & 2250 \\
\hline $\begin{array}{l}\text { Saving in } \\
\text { Index 25 }\end{array}$ & 17 & $\begin{array}{l}2026 \\
\mathrm{FI}_{i} \\
\mathrm{i}=2010\end{array}$ & $\begin{array}{l}2029 \\
\sum \mathrm{FI}_{i} \\
2010\end{array}$ \\
\hline $\begin{array}{l}\text { Saving in } \\
\text { Index 10 }\end{array}$ & 20 & $\mathrm{i}=$ & 2500 \\
\hline
\end{tabular}

After data collection was completed, repair cost is computed. Repair cost is required cost for components restoration to excellent condition (operating period) after corrosion, broken, and other. Repair and maintenance cost is dependent on condition of weather, maintenance method, components functions, and management quality. Therefore, cost quantities have high standard deviation and there may not be any methods for accurate prediction of cost variation during future years [24]. Repair and maintenance cost of facilities and components is very low during first month (approximately 0). Function and lifespan enhancement result in increasing repair cost and repair cost is equal to replacement cost during final years. The market price fluctuation is a problem in relation to the accurate prediction of repair and maintenance cost. Therefore, accurate information and suitable statistics are very complex for computing component repair cost in field of component repair and maintenance [24]. The equations estimate repair costs as a percentage of the component purchase price (component replacement cost), so the equations should remain valid as long as the component purchase price goes up at the same rate as the cost of repairs [25]. The formulas for repair and maintenance costs estimate total accumulated repair costs based on accumulated hours of lifetime use. Repair and maintenance calculations are based on American Society of Engineers formulas [26]. There are other relevant studies in the field of repair cost computations including Sajadi and Moghadam in 2005 [27] and Means in 2008 [28]. In this study, the repair cost is computed basing on existing definition of repair cost and condition index method. This section defines the repair cost using the existing statistics of construction industry. The repair cost is analyzed by using the economic techniques and financial issues in repair and maintenance based on existing definitions. This equation is linear and uses the 
virtual variable:

$$
\text { Cost repair }=\text { Cost replacement } \times((100-\mathrm{CI}) /(100-10))
$$

Here cost repair is estimated unit repair cost for the desired index, cost replacement is estimated unit replacement cost, and $\mathrm{CI}$ is current condition index of USACERL $(85,70,55,40,25,10)$.

The replacement cost is computed based on price of fiberglass door in the market, and its inflation rate during future years until 2029. The inflation rate is $2.6 \%$ based on average inflation rate of Malaysia from 1990 to 2010 [29]. Table 5 depicts the replacement cost of fiberglass doors at first year of operation up to future 20 years.

TABLE V

REPLACEMENT COST FOR FIBERGLASS DOORS FROM 2010 TO 2029

\begin{tabular}{c|c|c|c}
\hline Year & $\begin{array}{c}\text { Replacement } \\
\text { cost }(\$)\end{array}$ & Year & $\begin{array}{c}\text { Replacement } \\
\text { cost }(\$)\end{array}$ \\
\hline 2010 & 2000 & 2020 & 2586 \\
\hline 2011 & 2052 & 2021 & 2653 \\
\hline 2012 & 2105 & 2022 & 2722 \\
\hline 2013 & 2160 & 2023 & 2793 \\
\hline 2014 & 2216 & 2024 & 2866 \\
\hline 2015 & 2274 & 2025 & 2941 \\
\hline 2016 & 2333 & 2026 & 3017 \\
\hline 2017 & 2394 & 2027 & 3095 \\
\hline 2018 & 2456 & 2028 & 3175 \\
\hline 2019 & 2520 & 2029 & 3258 \\
\hline
\end{tabular}

Information related to the fiberglass doors component in building exterior system with a unit repair cost of $\$ 3258$ at year 2029 is arranged in Table 6 and modeled in Fig.3.

TABLE VI

UNIT REPAIR COST FOR FIBERGLASS DOORS

\begin{tabular}{l|l|l|l}
\hline Index & Defects & Action & $\begin{array}{l}\text { Cost } \\
(\$)\end{array}$ \\
\hline 85 & Damaged handle & Replace handle & 388 \\
\hline 70 & Damaged trim & Replace trim & 818 \\
\hline 55 & Crocked hinge & Replace hinge & 1326 \\
\hline 40 & Damaged frame & Repair frame & 1862 \\
\hline 25 & $\begin{array}{l}\text { Damaged } \\
\text { handle/trim }\end{array}$ & Replace handle and trim & 2514 \\
\hline 10 & $\begin{array}{l}\text { Complete } \\
\text { deterioration }\end{array}$ & $\begin{array}{l}\text { Replace frame, handle, trim, } \\
\text { and hinge }\end{array}$ & 3258 \\
\hline
\end{tabular}

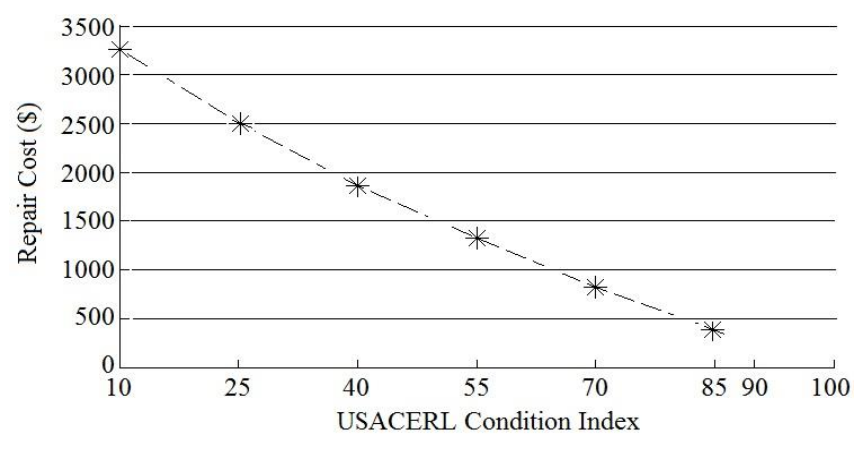

FIGURE III

UNIT REPAIR COST FOR FIBERGLASS DOORS OVER TIME

Simulating economic analysis is carried out basing on the saving to investment ratio (SIR) for maintenance at various condition index values for the fiberglass door component in the exterior system example in a public building. SIR is a numerical ratio and its size exhibits the economic execution of an investment. The SIR is saving divided by investment costs [30]. The SIR is illustrated by following equation (3):

$$
\text { SIR }=\text { Saving } \div \text { Investment }
$$

Here, saving is total annual maintenance budget until repair time and investment is repair cost in the year $i$.

The saving is calculated based on the budget collected for maintenance annually in part of component. Maintenance until year $i$. Table 7 and Fig. 4 present the SIR for maintenance at various condition index values for the fiberglass doors of public building in situations of predictive data.

TABLE VII

ECONOMIC ANALYSIS OF OPTIMUM REPAIR FOR FIBERGLASS DOORS BASED ON CONDITION INDEX VALUES

\begin{tabular}{c|c|c|c|c}
\hline $\begin{array}{c}\text { USACERL } \\
\text { Index }\end{array}$ & $\begin{array}{c}\text { Repair } \\
\text { year }\end{array}$ & $\begin{array}{c}\text { Investment } \\
(\$)\end{array}$ & $\begin{array}{c}\text { Saving } \\
(\$)\end{array}$ & SIR \\
\hline 85 & 7 & 388 & 400 & 1.03 \\
\hline 70 & 9.5 & 818 & 900 & 1.10 \\
\hline 55 & 12 & 1326 & 2000 & 1.65 \\
\hline 40 & 14.5 & 1862 & 2250 & 1.34 \\
\hline 25 & 17 & 2514 & 2350 & 1.01 \\
\hline 10 & 20 & 3258 & 2500 & 0.82 \\
\hline
\end{tabular}

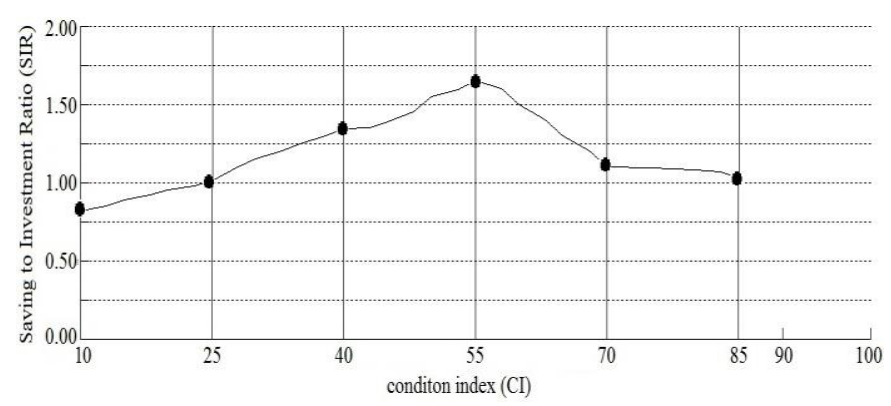

FIGURE IV

ECONOMIC ANALYSIS SimULATION FOR FACILITIES MAINTENANCE OF FIBERGLASS DOOR EXAMPLE

Table 7 and Fig.4 depict the analysis of optimum maintenance management of fiberglass door component example basing on a period of 20 years. The graph illustrates that when condition index reaches to 55, economic rate is high (SIR 1.65). Thus, the best time of maintenance occurs when $\mathrm{CI}$ is 55 with SIR 1.65. Building manager knows that the best decision for increasing component's service life based on existing budget is repair, cleaning, and service after 12 years $(\mathrm{CI}=$ 55 and SIR $=1.65)$. A ratio less than 1.0 indicates an uneconomic action [30]. When the ratio is below 1.0, the economic efficiency of maintenance actions are nearly equal the replacement. Thus, if $\mathrm{CI}<25$, replacement close to the CI terminal value of 10 should be replaced.

\section{CONCLUSIONS AND DISCUSSIONS}

The facilities management process model of public buil 
dings has been developed using the condition index metric, data collection methods and financial analysis for facilities correction assessment in buildings, in this case, $\mathrm{f}$ iberglass doors network. The development of the model in volves three stages process namely data collection, econo mic computation and economic process optimization. The systematic process has shown in a process model for facili ties maintenance management. The development process $\mathrm{i}$ $\mathrm{s}$ expected to help owners and building managers in decisi on making regarding facilities assessment time based on e xisting costs. This system controls existing investment in part of components maintenance and increases a facilities' service life and, eventually, prevents early deterioration an $\mathrm{d}$ components replacement in public buildings. This resear ch presented not only a process but also the framework an $\mathrm{d}$ techniques to manage and improve assessment effective ness and efficiency in fiberglass doors network of buildin gs. This study will be useful to researchers, facilities profe ssionals and others concerned with facilities management from both sides of the industry and academia. The resulte $\mathrm{d}$ process model is an integrated and comprehensive mode 1 that is able to clarify the process of building facilities ass essment. While the study focuses on fiberglass doors netw ork of public buildings, the process can also be used for ot her building facilities such as hospitals schools, office and commercial buildings components.

The information provided in this research contributes to the literature on financing and time prediction approaches and may serve as a resource for future studies. Based on $t$ he limited research studies related to financing and mainte nance time strategies of fiberglass doors in a public buildi ng, research might be conducted to model the financial sy stem and maintenance time prediction approaches in a co mprehensive system at public building facilities including various systems, components and materials; the settings c an be in different cities with different conditions. Future st udies should develop a way by which more field data abo ut sampling units (assessment projects) can be obtained to help the steering committee members in judging and ratin $\mathrm{g}$ different projects. More work should be done towards re cognizing the effects of using the appropriate techniques $\mathrm{s}$ pecifically on issues of cost effectiveness and budgeting $p$ olicy.

\section{REFERENCES}

[1] M. Fahiminia, "Wastewater engineering in the earthquake-prone regions." Proceeding of the 1st International Conference on Earthquake, Kerman, Iran, 2004. (In Persian).

[2] N. Amani, M.A. Nasly, R.S. Samat, "Infrastructure component assessment using the condition index system: literature review and discussion", Journal of Construction Engineering and Project Management, vol. 2, no. 1, pp. 27-34, 2012.

[3] G. Boyle, "Design Project Management", Burlington: NC Press, 2003.

[4] P.A. Tilley, S.L. McFallen, "Design and Documentation Quality Survey Designer's Perspectives", Melbourne: CSIRO Press, 2000.

[5] E.A.M. Mjema, "An analysis of personnel capacity requirement in the maintenance department by using simulation method", Journal of Quality in Maintenance, vol. 8, no. 3, pp. 253-273, 2002.

[6] N. Mohd-Noor, Y. Hamid, A.A. Ghani, S.N. Haron, "Building maintenance budget determination: an exploration study in the Malaysia government practice", Procedia Engineering, vol. 20, pp. 435-444, 2011.
[7] A.S. Ali, "Cost decision making in building maintenance practice in Malaysia", Journal of Facilities Management, vol. 7, no. 4, pp. 298-306, 2009.

[8] A.S. Ali, I. Rahmat, H. Hassan, "Involvement of key design participants in refurbishment design process", Facilities, vol. 26, no. 9-10, pp. 389-400, 2008.

[9] I. Rahmat, "Managing Refurbishment Projects", Shah Alam: Universiti Teknologi MARA Press, 2008.

[10] D.R. Uzarski, E.D. Lawson, M.Y. Shahin, D.E. Brotherson, "USACERL Development of the BUILDER Engineered Management System for BUILDING Maintenance: Initial Decision and Concept Report", Champaign: US Army Corps of Engineering Press, 1990

[11] D.R. Uzarski, D.K. Hicks, J.A. Zahorak, "USACERL-building and building component condition and capability metrics", Proceedings of the 7st International Conference on Application of Advanced Technology in Transportation, American Society of Civil Engineering, 2002.

[12] D.R. Uzarski, L.A. Burley, "USACERL-assessing building condition by the use of condition indexes", Proceedings of the ASCE Specialty Conference Infrastructure Condition Assessment: Art, Science, Practice, pp.365- 374, 1997.

[13] M.N. Grussing, "USACERL-building envelope life cycle condition evaluation using a distress-based methodology", Proceeding of the ASCE Specialty Conference Applications of Advanced Technology in Trans, Austin, Texas, pp. 2482-2490, 2009.

[14] BUILDER, "BUILDER Engineered Management System", Available from http://dwww.cecer.army.mil/td/tips/product

[15] D.R. Uzarski, "Development of Condition Indexes for Low Volume Railroad Track", Champaign: US Army Corps of Engineering Press, 1993.

[16] M.Y. Shahin, M.I. Darter, S.D. Kohn, "Development of a Pavement Maintenance Management System", Champaign: US Army Corps of Engineering Press, 1976

[17] M.Y. Shahin, S.D. Kohn, "Development of a Pavement Condition Rating Procedure for Roads, Streets, and Parking Lots", Champaign: US Army Corps of Engineering Press, 1979.

[18] M.Y. Shahin, D.M. Bailey, D.E. Brotherson, "Membrane and Flashing Condition Indexes for Built-up Roofs", Champaign: US Army Corps of Engineering Press, 1987.

[19] A. Kumar, W. Riggs, M. Blyth, "Demonstration of the Pipe corrosion Management System", Champaign: US Army Corps of Engineering Press, 1986.

[20] E. Koehn, A.M. Kao, "Evaluation of Existing Condition Rating Procedures for Civil Works Structures and Facilities", Champaign: US Army Corps of Engineering Press, 1986.

[21] D.R. Uzarski, "Development of a track structure condition index (TSCI)", Ph.D. Thesis, University of Illinois, Champaign, USA, 1991.

[22] Fibreglass doors, "What are the advantages of fibreglass doors", Available from http://www.wisegeek.com/what-are-theadvantages-of-fiberglass-doors.htm, 2003.

[23] Lose Angeles HOA Management, "Estimating useful life for capital assets", Available from http://www.homeownersassociationmanagementla.com/Estimating -Useful-Lives-of-Building-Components.html, 1993.

[24] M.R. Vafai, H. Mighani, A.M. Borghai, "Identification of mathematical model of maintenance and repair from Newholand machinery, TMISS Model", Journal of the Agriculture Modern Findings, vol. 2, no. 2, pp. 190-199, 2007.

[25] W.F. Lazarus, "Estimating Farm Machinery Repair Costs", Minnesota: University of Minnesota Press, 2008.

[26] W.F. Lazarus, "Machinery Cost Estimates", Minnesota: University of Minnesota Press, 2012.

[27] S.J. Sajadi, B. Moghadam, "Cost assessment of maintenance and repair in industrial", Proceedings of the 3st National Conference in Maintenance and Repair, Tehran, Iran, 2005. (In Persian)

[28] R.S. Means, "Square Foot Costs", 29th Annual Edition: RS Means Company Inc, 2008

[29] Index Mundi, "Equivalent data from the international monetary fund", Available from

http://www.indexmundi.com/malaysia/inflation_rate_\%28consume r_prices\%29.html, 2011.

[30] T.R. Ruegg, H.E. Marshall, "Building Economic: Theory and Practice", New York: Van Nostrand Reinhold- VNR Press, 2003. 